\title{
MECP2 Duplication Syndrome
}

\author{
H. Van Esch \\ Centre for Human Genetics, University Hospitals Leuven, Leuven, Belgium
}

\section{Key Words}

Array comparative genomic hybridization - Duplication • Epilepsy - Hypotonia - Intellectual disability $\cdot$ MECP2 Recurrent infections $\cdot$ Spasticity $\cdot X$ chromosome $\cdot$ Xq28

\begin{abstract}
Since the initial report that clearly established a causal role between duplication of the MECP2 gene and a severe syndromic form of intellectual disability, many new patients have been identified and reported, and the etiology in already published families solved. This has led to the establishment of a clinically recognizable disorder. Here, we review the clinical data of 129 reported and nonreported male patients with MECP2 duplication syndrome.
\end{abstract}

Copyright $\odot 2011$ S. Karger AG, Basel

\section{History}

The advent of array-based comparative genomic hybridization has contributed significantly to the field of intellectual disability (ID). Not only are new syndromes and genes being identified at a rapid pace, but also new genetic mechanisms leading to disease are being unraveled. The identification of duplications involving the
MECP2 gene and hence increased MECP2 protein dosage as causal for a severe syndromic form of ID in males was at first surprising [Van Esch et al., 2005]. Until then, $M E C P 2$ was considered an almost exclusive female topic. However, fundamental studies in mice had already shown that overexpression of mouse and also human protein resulted in a progressive neurological disorder [Collins et al., 2004; Luikenhuis et al., 2004] and it had been hypothesized that $M E C P 2$ overexpression could lead to a postnatal neurological phenotype in human [Collins et al., 2004].

Since the initial report that clearly established a causal role between duplication of the MECP2 gene and a severe syndromic form of ID, many new patients have been identified and reported, and the etiology in already published families solved [Lubs et al., 1999; Meins et al., 2005; Van Esch et al., 2005; del Gaudio et al., 2006; Friez et al., 2006; Bauters et al., 2008; Smyk et al., 2008; ClaytonSmith et al., 2009; Echenne et al., 2009; Kirk et al., 2009; Lugtenberg et al., 2009; Prescott et al., 2009; Velinov et al., 2009; Bartsch et al., 2010; Belligni et al., 2010; Fernandez et al., 2010; Ramocki et al., 2010; Reardon et al., 2010]. The comparison of all these reported male patients enabled the establishment of a clinically recognizable disorder (table 1).

\section{KARGER}

Fax +4161306 1234

E-Mail karger@karger.ch

www.karger.com
(C) 2011 S. Karger AG, Basel

$1661-8769 / 11 / 0025-0128 \$ 38.00 / 0$

Accessible online at:

www.karger.com/msy
Hilde Van Esch

Centre for Human Genetics

University Hospitals Leuven

Herestraat 49, BE-3000 Leuven (Belgium)

Tel +32 16345 903, E-Mail Hilde.Vanesch@med.kuleuven.be 


\section{Clinical Features}

In table 1, the clinical features and their incidence are listed, based on the review of the literature combined with clinical data on 15 nonreported patients known to the author. These numbers are far from complete and depend on the completeness of the reports and, more importantly, on the age of the patients at the time of description, especially since some of the clinical features change with age.

The cardinal features of the MECP2 duplication syndrome include early infantile hypotonia, delayed psychomotor development resulting in severe to profound ID with absent to very limited speech and neurological symptoms, including abnormal gait, epilepsy and spasticity. In the majority of patients, recurrent infections, especially of the respiratory tract occur, and often gastrointestinal motility problems are present. In those patients who underwent brain imaging, 3 in 4 were reported to have structural and even progressive anomalies. Dysmorphism is common and some facial features are shared by several patients.

\section{Psychomotor Development}

During the first weeks of life, feeding difficulties resulting from hypotonia may become evident in affected males. The child is floppy and may also exhibit difficulty with swallowing, gastro-esophageal reflux, failure-tothrive, and extensive drooling, sometimes necessitating nasogastric tube feeding.

As a result of the axial hypotonia, motor developmental milestones including sitting and crawling are delayed in almost all patients. Hence, walking is also severely delayed (range 18 months- 4 years) but 3 in 4 males ultimately achieve ambulation without support; however, gait is often ataxic and several affected boys develop a compensating lumbar hyperlordosis. However, with increasing age, many patients manifest a neurological and general regression that will ultimately result in loss of ambulation. The same holds true for speech development. The majority of affected individuals $(\sim 80 \%)$ do not develop speech. In some individuals who were able to speak a few single words in early childhood, speech was progressively lost in adolescence. Recurrent infections and refractory epilepsy may be contributing factors to regression, but the true physiologic/molecular cause remains unclear. Further fundamental studies are necessary to elucidate the effect of increased MECP2 dosage on the human brain. In addition, we cannot exclude a possible influence of increased gene dosage of other genes within the respective duplicated regions. Most affected males function at the level of moderate to severe ID and require lifelong specialized care.

\section{Neurological Symptoms and Behavior}

In $75 \%$ of affected males, the early hypotonia gives way to spasticity in childhood. However, the first pyramidal signs may already appear during the first years of life. The spasticity is more pronounced in the lower limbs and mild to severe contractures of hips, knees and ankles may develop over time. Often the use of a wheelchair becomes necessary in early adulthood. In some patients, the use of botulinum toxin A injections can be considered. Importantly, this should happen on an individual basis, within an expert multidisciplinary clinical setting with the necessary physiotherapeutic support. Botox infiltrations might be beneficial to keep the patient ambulatory and to prevent joint dislocations, especially of the hips.

Seizures are seen in 54\% of individuals. Age of seizureonset is very variable and in some patients they only appeared during the second decade of life, so $54 \%$ may be an underestimate. Generalized tonic-clonic seizures are most often observed, but atonic seizures, absences and also myoclonic seizures have been described. In some individuals, seizures were very refractory to treatment and it is often noted that the onset and the severity of the seizures correlate with neurological deterioration, characterized by loss of speech, hand use, and/or ambulation. Echenne et al. [2009] reported the electroencephalographic findings in 5 of their affected patients who exhibited myoclonic-astatic seizures. These electroencephalograms showed unusual, very slow background activity and multifocal theta or delta waves associated with focal or generalized spike-waves, instead of the expected rapid rhythm and poly-spike waves. This slow background activity was also seen in the patients reported by Ramocki et al. [2010], and in several of our unreported patients.

In some patients, autistic features, stereotypic behavior or mood disorders were observed [Meins et al., 2005; del Gaudio et al., 2006]. Ramocki et al. [2010] reported abnormal movements in 9 patients, including choreiform movements of the upper limbs and hands and also of the head and tongue. In addition, they observed stereotypic midline hand movements. This was also present in the patient reported by Meins et al. [2005].

\section{Neuroradiology}

In the majority of patients with a $M E C P 2$ duplication who underwent brain imaging, neuroradiological abnormalities were present. Although the presentation of these 
Table 1. Clinical findings present in male patients with microduplications involving MECP2

\begin{tabular}{|c|c|c|c|c|c|c|c|c|c|}
\hline Report & $\begin{array}{l}\text { Meins et al. } \\
{[2005]}\end{array}$ & $\begin{array}{l}\text { Van Esch et al. } \\
\text { [2005] }\end{array}$ & $\begin{array}{l}\text { Friez et al. } \\
{[2006]}\end{array}$ & $\begin{array}{l}\text { del Gaudio et al. } \\
\text { [2006] }\end{array}$ & $\begin{array}{l}\text { Lugtenberg et al. } \\
\text { [2009] }\end{array}$ & $\begin{array}{l}\text { Smyk et al. } \\
{[2008]}\end{array}$ & $\begin{array}{l}\text { Clayton-Smith et al. } \\
\text { [2009] }\end{array}$ & $\begin{array}{l}\text { Velinov et al. } \\
\text { [2009] }\end{array}$ & $\begin{array}{l}\text { Kirk et al. } \\
\text { [2009] }\end{array}$ \\
\hline \multirow{3}{*}{$\begin{array}{l}\text { No. of patients } \\
\text { Severe ID } \\
\text { Infantile } \\
\text { hypotonia }\end{array}$} & 1 & 13 & 23 & 7 & 13 & 3 & 16 & 1 & 3 \\
\hline & $1 / 1$ & $12 / 12$ & $23 / 23$ & $7 / 7$ & $13 / 13$ & $3 / 3$ & $16 / 16$ & $1 / 1$ & $3 / 3$ \\
\hline & $1 / 1$ & $12 / 12$ & $17 / 20$ & $7 / 7$ & $11 / 13$ & $2 / 2$ & $15 / 16$ & $1 / 1$ & $3 / 3$ \\
\hline \multirow{3}{*}{$\begin{array}{l}\text { Absent speech } \\
\text { Lack of } \\
\text { ambulation } \\
\text { Walking (with } \\
\text { support) }\end{array}$} & $1 / 1$ & $10 / 12$ & $18 / 19$ & $6 / 7$ & $10 / 13$ & $1 / 3$ & 9/11 & $1 / 1$ & $1 / 2$ \\
\hline & $0 / 1$ & $7 / 12$ & $7 / 19$ & $1 / 7$ & $0 / 12$ & $0 / 2$ & $5 / 12$ & $0 / 1$ & $0 / 3$ \\
\hline & $1 / 1$ & $5 / 12$ & $12 / 19$ & $6 / 7$ & $12 / 12$ & $2 / 2$ & $7 / 12$ & $1 / 1$ & $3 / 3$ \\
\hline Spasticity & $0 / 1$ & $9 / 9$ & $7 / 10$ & NR & $6 / 13$ & $3 / 3$ & $4 / 16$ & $0 / 1$ & $2 / 2$ \\
\hline Epilepsy & $1 / 1$ & $4 / 9$ & $15 / 23$ & $1 / 7$ & $7 / 13$ & $0 / 3$ & $8 / 16$ & $0 / 1$ & $2 / 3$ \\
\hline $\begin{array}{l}\text { Recurrent } \\
\text { infections }\end{array}$ & NR & $5 / 9$ & $22 / 23$ & $4 / 7$ & $3 / 13$ & $0 / 2$ & $15 / 16$ & $0 / 1$ & $2 / 3$ \\
\hline \multicolumn{10}{|l|}{ Early death } \\
\hline$<25$ years & NA & $6 / 11$ & $12 / 23$ & NR & $1 / 5$ & $1 / 3$ & $5 / 12$ & $0 / 1$ & $1 / 2$ \\
\hline Constipation & $0 / 1$ & $0 / 12$ & NR & NR & $2 / 13$ & NR & $14 / 16$ & $0 / 1$ & $0 / 3$ \\
\hline Stereotypies & $1 / 1$ & NR & NR & $1 / 7$ & $1 / 13$ & NR & $3 / 16$ & $0 / 1$ & $0 / 3$ \\
\hline Dysmorphism & $\begin{array}{l}1 / 1 \\
\text { narrow } \\
\text { midface }\end{array}$ & $\begin{array}{l}8 / 8 \\
\text { large ears, } \\
\text { flat midface, } \\
\text { deep-set eyes }\end{array}$ & $\begin{array}{l}4 / 4 \\
\text { small mouth } \\
\text { prominent } \\
\text { lips }\end{array}$ & $\begin{array}{l}4 / 7 \\
\text { flat midface, } \\
\text { large ears, } \\
\text { prominent } \\
\text { nasal bridge, } \\
\text { deep-set eyes }\end{array}$ & $\begin{array}{l}10 / 13 \\
\text { large ears, } \\
\text { broad nasal root, } \\
\text { flat midface }\end{array}$ & $\begin{array}{l}2 / 3 \\
\text { prominent forehead, } \\
\text { downslanting } \\
\text { palpebral fissures, } \\
\text { broad nasal root, } \\
\text { large ears }\end{array}$ & $\begin{array}{l}15 / 16 \\
\text { narrow nose, } \\
\text { prominent forehead, } \\
\text { deep-set eyes }\end{array}$ & $\begin{array}{l}1 / 1 \\
\text { large ears }\end{array}$ & NR \\
\hline $\begin{array}{l}\text { Brain } \\
\text { anomalies }\end{array}$ & $\begin{array}{l}1 / 1 \\
\text { mildly } \\
\text { enlarged } \\
\text { ventricles, } \\
\text { unspecific } \\
\text { white matter } \\
\text { changes }\end{array}$ & $\begin{array}{l}3 / 4 \\
\text { delayed } \\
\text { myelination, } \\
\text { cortical } \\
\text { atrophy, } \\
\text { ventricular } \\
\text { dilatation }\end{array}$ & $\begin{array}{l}2 / 3 \\
\text { gray matter } \\
\text { heterotopia, } \\
\text { ACC }\end{array}$ & NR & $\begin{array}{l}6 / 9 \\
\text { increased signal in } \\
\text { the posterior white } \\
\text { matter, superior } \\
\text { vermis atrophy, } \\
\text { cerebral atrophy, } \\
\text { ventricular dilatation }\end{array}$ & $\begin{array}{l}1 / 2 \\
\text { delayed myelination }\end{array}$ & $\begin{array}{l}6 / 9 \\
\text { ventricular dilatation, } \\
\text { delayed myelination, } \\
\text { partial ACC, hypoplasia } \\
\text { cerebellar vermis }\end{array}$ & $\begin{array}{l}1 / 1 \\
\text { large cisterna } \\
\text { magna }\end{array}$ & $\begin{array}{l}2 / 3 \\
\text { increased } \\
\text { signal in the } \\
\text { periventricular } \\
\text { white matter }\end{array}$ \\
\hline Other & & $\begin{array}{l}\text { AP: diffuse } \\
\text { gliosis of the } \\
\text { white matter, } \\
\text { diffuse cerebral } \\
\text { neuronal loss }\end{array}$ & & $\begin{array}{l}\text { cryptorchidism, } \\
\text { hypospadias, } \\
\text { hydronephrosis, } \\
\text { duplex urethra }\end{array}$ & cryptorchidism & cryptorchidism & & & \\
\hline
\end{tabular}

ACC = Agenesis of corpus callosum; $\mathrm{AP}=$ anatomopathology; $\mathrm{CC}=$ corpus callosum; $\mathrm{ID}=$ intellectual disability; NA = not applicable; $\mathrm{NR}=$ not reported; $\mathrm{PDA}=$ persistent ductus arteriosus.

data are not very consistent, some characteristics are emerging, including generalized ventricular dilatation, cortical atrophy, hypoplasia of the corpus callosum and increased signal in the periventricular white matter, especially in the posterior regions of the brain (table 1). It is very possible that some of these abnormalities are secondary to the long-standing and frequent seizures some of these patients experience. Interesting, however, is the report by Reardon et al. [2010] that describes a progressive neuroradiological phenotype in patients with MECP2 duplications. These authors present successive neuroradiological images over several years in 3 patients, showing progressive cerebellar degenerative changes, even in an affected male who did not experience seizures. Therefore, it was postulated that these progressive changes are directly related to the duplication, rather than to a sec- ondary seizure-related event. Unfortunately, consecutive neuroradiological studies are rare in the severely affected patients older than 10 years of age.

\section{Recurrent Infections}

Recurrent infections, especially of the respiratory tract and often requiring hospitalization, intravenous antibiotics therapy and even assisted ventilation, occur in $70 \%$ of affected individuals. In a minority of patients, a tracheostomy is required. Other types of infections, such as meningitis and urinary tract infections have also been described. These recurrent infections may lead to further deterioration of the general and neurological status, and in some patients they can be fatal. Together with the refractory epilepsy and the neurological deterioration, these infections are responsible for the early death report- 


\begin{tabular}{|c|c|c|c|c|c|c|c|c|}
\hline $\begin{array}{l}\text { Prescott et al. } \\
\text { [2009] }\end{array}$ & $\begin{array}{l}\text { Echenne et al. } \\
\text { [2009] }\end{array}$ & $\begin{array}{l}\text { Bartsch et al. } \\
{[2010]}\end{array}$ & $\begin{array}{l}\text { Fernandez et al. } \\
{[2010]}\end{array}$ & $\begin{array}{l}\text { Ramocki } \\
\text { et al. [2009] }\end{array}$ & $\begin{array}{l}\text { Belligni et al. } \\
\text { [2010] }\end{array}$ & $\begin{array}{l}\text { Reardon et al. } \\
\text { [2010] }\end{array}$ & unreported & $\%$ \\
\hline 2 & 5 & 4 & 1 & 14 & 1 & 7 & 15 & 129 patients \\
\hline $2 / 2$ & $5 / 5$ & $4 / 4$ & $1 / 1$ & $14 / 14$ & $1 / 1$ & $7 / 7$ & $13 / 13$ & 100 \\
\hline $2 / 2$ & $5 / 5$ & $4 / 4$ & $1 / 1$ & $9 / 9$ & $1 / 1$ & $5 / 6$ & $14 / 14$ & 94 \\
\hline $2 / 2$ & $4 / 4$ & $3 / 4$ & $1 / 1$ & $7 / 9$ & NA & $6 / 6$ & $6 / 14$ & 79 \\
\hline $0 / 2$ & $1 / 5$ & $1 / 4$ & $1 / 1$ & $1 / 9$ & NA & $1 / 7$ & $1 / 12$ & 24 \\
\hline $2 / 2$ & $4 / 5$ & $3 / 4$ & $0 / 1$ & $8 / 9$ & NA & $6 / 7$ & $11 / 12$ & 76 \\
\hline $1 / 2$ & $5 / 5$ & $3 / 3$ & NR & $8 / 9$ & NA & $2 / 5$ & $7 / 10$ & 64 \\
\hline $1 / 2$ & $3 / 5$ & $2 / 4$ & $1 / 1$ & $9 / 14$ & NR & $4 / 7$ & $8 / 14$ & 54 \\
\hline $2 / 2$ & $0 / 5$ & $4 / 4$ & $1 / 1$ & $12 / 14$ & $1 / 1$ & $7 / 7$ & $9 / 13$ & 72 \\
\hline NA & $0 / 5$ & NA & NA & $5 / 14$ & NA & $2 / 7$ & $1 / 5$ & 39 \\
\hline $1 / 2$ & $0 / 5$ & $3 / 4$ & $1 / 1$ & $5 / 9$ & $1 / 1$ & $0 / 7$ & $2 / 13$ & 33 \\
\hline $0 / 2$ & $1 / 1$ & $2 / 4$ & NR & $9 / 9$ & NA & $0 / 7$ & $2 / 14$ & 25 \\
\hline $2 / 2$ & $\begin{array}{l}5 / 5 \\
\text { large ears }\end{array}$ & $\begin{array}{l}4 / 4 \\
\text { large ears, } \\
\text { broad nasal } \\
\text { root }\end{array}$ & $\begin{array}{l}1 / 1 \\
\text { long face, } \\
\text { downslanting } \\
\text { palpebral } \\
\text { fissures, } \\
\text { strabismus }\end{array}$ & NR & NR & $0 / 7$ & $\begin{array}{l}8 / 14 \\
\text { low hairline, large ears, } \\
\text { synophris, bifid uvula }\end{array}$ & 75 \\
\hline \multirow[t]{2}{*}{$\begin{array}{l}2 / 2 \\
\text { increased } \\
\text { extra } \\
\text { cerebral } \\
\text { fluid }\end{array}$} & $\begin{array}{l}2 / 5 \\
\text { cortical atrophy, } \\
\text { white matter } \\
\text { abnormalities }\end{array}$ & $\begin{array}{l}3 / 4 \\
\text { ventricular } \\
\text { dilatation, } \\
\text { hypoplasia CC }\end{array}$ & $\begin{array}{l}1 / 1 \\
\text { ventricular } \\
\text { dilatation }\end{array}$ & NR & NR & $\begin{array}{l}7 / 7 \\
\text { progressive } \\
\text { reduction white } \\
\text { matter and inferior } \\
\text { cerebellar atrophy }\end{array}$ & $\begin{array}{l}7 / 10 \\
\text { hypoplasia CC, } \\
\text { ventricular dilatation, } \\
\text { hypoplasia vermis, } \\
\text { increased signal white } \\
\text { matter posteriorly }\end{array}$ & 72 \\
\hline & & cryptorchidism & $\begin{array}{l}\text { Hirschsprung } \\
\text { disease, } \\
\text { cryptorchidism }\end{array}$ & & $\begin{array}{l}\text { congenital central } \\
\text { hypoventilation, } \\
\text { PDA }\end{array}$ & & $\begin{array}{l}\text { tri-atrial heart, } \\
\text { clinodactyly }\end{array}$ & \\
\hline
\end{tabular}

ed in many individuals, the diagnosis often being made retrospectively. It is difficult to give a precise number on early deaths before the age of 25 years, because many of the recently published patients are still young and were diagnosed early. Therefore, the statistical percentage of $39 \%$ is likely an underestimate.

The IRAK1 gene maps between LICAM and MECP2 and is duplicated in almost all patients reported to date. This gene encodes an interleukin receptor-associated kinase involved in the toll-like receptor transduction pathway, a pathway that is important for immunity against certain pyogenic bacteria. By means of their kinase and adaptor functions, IRAKs initiate a cascade of signaling events eventually leading to induction of inflammatory target gene expression. Interestingly, we and others have found that affected boys do not respond adequately to vaccines containing polysaccharide antigens (e.g. Streptococcus pneumoniae, Haemophilus influenzae type B, Neisseria meningitidis) and often require extra boosters [Friez et al., 2006; Prescott et al., 2009]. The same authors also performed immunological laboratory investigations, including T- and B-cell numbers, T-cell functional studies, serum immunoglobulin levels (IgM, IgE, IgA, $\operatorname{IgD}$ and IgG plus subclasses) and complement activity, but could not detect consistent abnormalities that could explain the occurrence of the recurrent infections [Friez et al., 2006; Prescott et al., 2009]. In addition, we specifically challenged the IRAK1 pathway in 3 affected patients and 5 age-matched controls. Fresh blood lymphocytes were stimulated by ionomycin (PMA-IONO), recombinant human IL1 beta or heat-killed S. pneumoniae serotype 3 and subsequently, TNF and IL- 8 production was 
measured. We did not, however, see any differences in cytokine production between affected and controls (results not shown). Taken together, the effect of duplication of IRAK1 in humans, and its role in the observed immunological problems present in many MECP2 duplication patients is far from clear. It is possible that other duplicated gene(s) or even disruption of regulatory elements nearby contribute to the immune system dysfunction. Our experience is that, provided the first severe infections are well managed, this proneness to infections has the tendency to improve spontaneously with increasing age. Nevertheless, infections should be treated aggressively and appropriately.

\section{Gastrointestinal Problems}

Gastrointestinal problems have often been reported in individuals with Xq28 duplications. Gastro-oesophageal reflux and swallowing dysfunction are frequent in the hypotonic affected infant and may contribute to the recurrent respiratory infections during the first years of life. In some patients, fundoplication or permanent gastrostomy clearly improved the respiratory distress and their general feeding condition.

Clinically important constipation is reported in more than one third of the patients. Constipation is in general a frequent problem in the large group of patients with severe mental and motor problems. However, the report by Clayton-Smith et al. [2009] is interesting as they describe several patients with Xq28 duplications who suffered from chronic intestinal pseudo-obstruction, a serious gastrointestinal dysmotility syndrome, and bladder dysfunction. Hirschsprung disease (HSCR) was ruled out in some of them. The authors state that duplication of the FLNA gene, localized telomeric to MECP2, may well be responsible for the intestinal pseudo-obstruction in these patients. This is further corroborated by previous reports of FLNA mutations in X-linked families with intestinal pseudo-obstruction [Hehr et al., 2006; Gargiulo et al., 2007]. Although not all patients with an FLNA duplication suffer from constipation, this observation has raised awareness for this particular symptom.

\section{Dysmorphism}

In young patients, a hypotonic face with tented upper lip, open mouth and often excessive drooling is present. In older patients, additional facial features become more recognizable. Many patients have, in addition to the facial hypotonia, deep-set eyes, a narrow nose, prominent chin, and large ears [Clayton-Smith et al., 2009].
Growth parameters, in particular head circumference, are generally within the normal range, in contrast to the microcephaly observed in the classical Rett syndrome. However, due to the prolonged hypotonia, the skull shape is often asymmetric.

\section{Other Reported Features}

In a recent report, Fernandez et al. [2010] reported a patient with HSCR and a duplication of the Xq28 region including MECP2 ( $300 \mathrm{~kb})$. The authors excluded mutations in RET and 6 other HSCR-related genes as causal for the HSCR, and suggested that the enteric phenotype could be due to increased dosage of L1CAM in combination with additional molecular events not yet identified. This hypothesis is supported by the fact that mutations in L1CAM have been found in patients who present with $\mathrm{X}$ linked hydrocephalus and HSCR.

Interestingly, another neurocristopathy, namely congenital central hypoventilation syndrome was reported in another patient with a small MECP2 duplication [Belligni et al., 2010]. Pathogenic mutations in PHOX2B and $R E T$ were excluded. This child also suffered from severe constipation, but HSCR was excluded by rectal biopsy. It will be of interest to see whether these patients represent unique cases or whether neurocristopathies can be considered as part of the syndrome, especially in patients with increased dosage of L1CAM.

\section{Carrier Females}

Most MECP2 duplications identified in males are inherited from a carrier mother, who is asymptomatic, because of extreme ( $>90 \%)$ to complete skewing of X chromosome inactivation with the duplication-bearing $\mathrm{X}$ chromosome being preferentially inactivated [Van Esch et al., 2005]. One study reported neuropsychiatric symptoms, including depression, anxiety and autistic features, in female carriers who have normal intellectual abilities [Ramocki et al., 2009].

More recent reports, however, also describe mildly affected female carriers who do not show complete skewing. Reardon et al. [2010] reported a mildly affected sister of an affected boy, with X-inactivation ratio (XCI) of 30/70 in blood. Kirk et al. [2009] found a different XC ratio in hair roots $(26 / 74)$ than in peripheral blood $(100 / 0)$ in a mildly affected mother. Hence, it seems that $70 \%$ skewing or less is sufficient to cause mild learning problems in females. But more importantly, these findings complicate genetic and prenatal counseling, and more detailed and larger studies on female carriers are mandatory. 


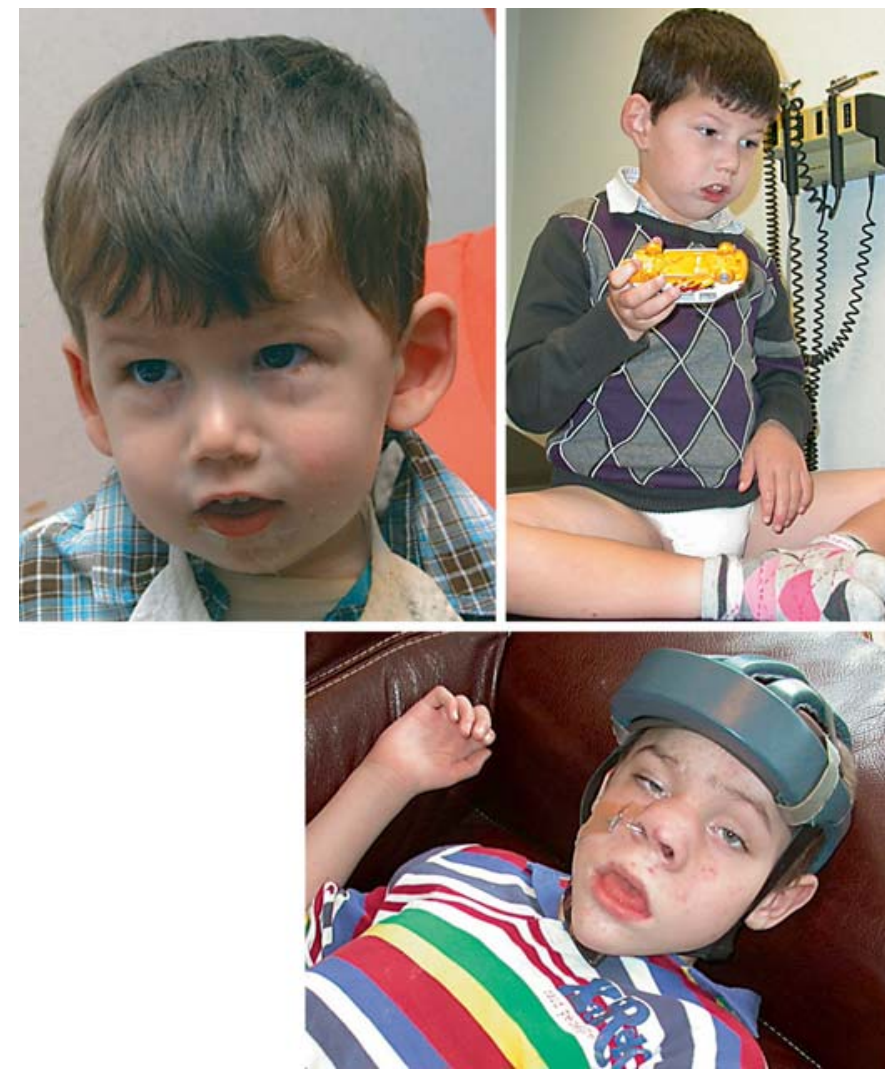

Fig. 1. Upper panel: male patient with $M E C P 2$ duplication at age 2 (left) and age 5 (right). Note the hypotonic face with tented upper lip, open mouth and excessive drooling as well as the deep-set eyes and narrow nose. Lower panel: 15-year-old boy who regressed after onset of severe therapy-resistant epilepsy. Note the coarse hypotonic face and malformed nose due to the frequent drop attacks and chronic nasogastric tube feeding.

In contrast to the familial female cases, de novo duplications involving $M E C P 2$ resulting in a clinical phenotype have also been reported in females. In the majority of cases, the females are symptomatic because the duplicated region is functionally active due to translocation to an autosome. In these situations, a phenotype as severe as in males is present [Lachlan et al., 2004; Sanlaville et al., 2005; Auber et al., 2010; Makrythanasis et al., 2010]. In addition, Grasshoff et al. [2011] reported on 2 female patients with a de novo submicroscopic MECP2 duplication that occurred on the paternal allele. These 2 females presented with unspecific mild-to-moderate ID, autistic features, and recurrent infections in early childhood, constipation and late-onset neurological features in 1 of them. Both females had random XCI. These authors propose that de novo occurrence of the MECP2 duplication might have an effect on the XCI by preventing a protec- tive 'mutation-induced' skewed XCI by a yet unrecognized mechanism. This would mean that there could be a different trigger for the methylation process from an inherited MECP2 duplication than from the one that occurred de novo. Another possible explanation may be a postzygotic mosaic occurrence of the duplication, but the authors could not find clinical or molecular evidence for this mechanism [Grasshoff et al., 2011].

\section{Genotype-Phenotype Correlation}

To date, more than 110 patients have been reported, nearly all with different duplication sizes and breakpoints, and it is indisputable that increased dosage of MECP2 is sufficient to cause the core phenotype (table 1). The smallest duplication, identified by several authors, only contains the IRAK1 and MECP2 genes and were found in affected males who presented with developmental delay, epilepsy, spasticity and recurrent lung infections [del Gaudio et al., 2006; Bauters et al., 2008; Lugtenberg et al., 2009]. Many authors have tried to further dissect the different Xq28 duplications in order to identify genes that contribute to the clinical spectrum. The potential involvement of IRAK1, LICAM, and FLNA has been discussed above. We cannot exclude that other (ID) genes within the duplicated region exert an additive effect. In this regard, we recently identified several families with ID, carrying duplications of the $\mathrm{Xq} 28$ region, not involving MECP2 [Vandewalle et al., 2009]. Interestingly, also patients with a triplication of MECP2 have been identified. These patients exhibited a very poor development, showing that MECP2 dosage apparently correlates with severity [del Gaudio et al., 2006].

Besides the submicroscopic rearrangements involving $M E C P 2$, which are the focus of this review, also larger, cytogenetically visible rearrangements involving Xq28 and MECP 2 in particular have been reported [Lachlan et al., 2004; Sanlaville et al., 2005]. About 40 cases of Xq28 functional disomy due to cytogenetically visible rearrangements have been described and in the majority of them, an unbalanced X/Y or X/autosome translocation underlies the functional disomy. Rearrangement sizes are much larger and vary between 8 and $23 \mathrm{Mb}$, often also comprising cytogenetic band Xq27. As expected, the clinical phenotype in these patients is severe and largely overlaps with the phenotype associated with the microscopic duplications involving MECP2. However, in these patients additional clinical features are often present, like pre- and postnatal growth deficiency, inguinal hernia and palatal and genital anomalies. This indicates that 
there are other genes in the large duplicated region that are dosage sensitive and exert an effect.

These large cytogenetically visible duplications have also been found in severely affected females with a functional Xq28 duplication without skewing of X chromosome inactivation. In most of these females, the duplication arises from an unbalanced $\mathrm{X}$-autosomal translocation or a genomic insertion elsewhere in the genome, explaining the absence of skewing of the aberrant X chromosome [Lachlan et al., 2004; Sanlaville et al., 2005; Makrythanasis et al., 2010].

\section{Incidence}

The overall prevalence of this condition is estimated to be $1 \%$ of unexplained X-linked ID [Lugtenberg et al., 2009]. In 2 separate studies, duplications were found in $1.6-2.2 \%$ of male patients, specifically referred for MECP2 molecular analysis [del Gaudio et al., 2006; Lugtenberg et al., 2009]. The more stringent the inclusion criteria are (core features, linkage to Xq28), the higher is the likelihood of identifying a MECP2 duplication, with estimates as high as 15\% [Van Esch et al., 2005; Ramocki et al., 2010].

To date, all reported microduplications in males were inherited from a carrier mother except one. However, this de novo microduplication of $2.15 \mathrm{Mb}$ was reported in a patient with a de novo Xq/Yq translocation [Velinov et al., 2009].

\section{Management}

Patients with MECP2 duplication syndrome manifest many different problems, necessitating a lifelong multidisciplinary approach. From infant age on, feeding and swallowing problems should be monitored to prevent aspiration pneumonia, optimize the general condition and prevent malnutrition of the child. Removal of adenoids can be beneficial for those children who manifest obstructive sleep and upper airway obstruction. However, good clinical indications should still drive the decision to pursue surgical intervention, and every child needs a tailored approach.

Given the many neurological problems, evaluation, treatment and follow-up by a pediatric neurologist and rehabilitation specialist are essential. Developmental stimulation including physiotherapy, speech and communication therapy is extremely important and should be adapted to the individual needs of the patients. Also, the spasticity should be monitored to prevent secondary contractures, and in some patients the use of botulinum toxin can be considered. However, this has to be performed in an expert multidisciplinary clinical setting with the necessary physiotherapeutic support, weighing advantages and disadvantages for each individual patient.

Diagnosis of type and frequency of seizures should be done by clinical history and electroencephalogram. If seizures are present, they usually respond well to standard therapy with anti-epileptic drugs; however, a subset of affected males experience treatment refractory seizures, and in this group neurological deterioration and regression often occurs.

Given the predisposition to infections, especially of the respiratory tract, they should be treated immediately and aggressively with appropriate antibiotics. Often hospitalization and even assisted ventilation is necessary. There is much debate about the use of prophylactic antibiotics in children with the MECP2 duplication. Given the low immunological response to vaccines containing polysaccharide antigens, administration of a booster might be considered.

\section{Molecular Genetics and Diagnosis}

Most patients have been identified by array comparative genome hybridization technologies, since this technique has become the standard in the diagnostic work-up of patients with developmental delay. Other quantitative methods such as quantitative real-time PCR or MLPA can also be used for direct clinical testing or confirmation of array results.

The sizes of the reported duplications vary between $300 \mathrm{~kb}$ and $4.2 \mathrm{Mb}$, and are too small to be detected by classical chromosome analysis. This is in contrast to the larger, cytogenetically visible duplications of the Xq28 region that also involve MECP2, discussed in the Genotype-Phenotype Correlation section.

Several groups already reported $\mathrm{Xq} 28$ as a region at high risk for genomic instability [Aradhya et al., 2002; Sanlaville et al., 2005]. The MECP2 duplications are nonrecurrent with unique duplication sizes and breakpoints. Two groups studied the underlying mechanism(s). They both showed that, even though some breakpoint regions coincide with low copy repeats, none of the duplications appear to be the result of nonallelic homologous recombination [Bauters et al., 2008; Carvalho et al., 2009]. 
Moreover, some of the duplications are much more complex than previously thought: both groups found stretches of nonduplicated sequences within the duplicated region, and in some patients the duplication contained an embedded triplicated segment. Both nonhomologous end joining followed by break-induced repair as well as fork stalling and template switching were proposed as mechanisms that could explain these rearrangements [Bauters et al., 2008; Carvalho et al., 2009].

\section{Future Perspectives}

The report of more than 100 patients with duplication of the MECP2 gene has now permitted the delineation of a clinical recognizable ID syndrome. Therefore, copy number testing for MECP2 should be included in the diagnostic workup of all male patients with moderate to severe ID and neurological symptoms. Molecular karyotyping is currently the standard diagnostic test because it also provides data on size and gene content of the Xq28 rearrangement. To date, there exists no cure and individuals with $M E C P 2$ duplication syndrome require lifelong multidisciplinary care to maximize function and prevent regression. The ongoing fundamental research in the field of MECP2 and its related disorders will give insights into the molecular and cellular functioning of this protein, which is crucial for normal human brain functioning and development. Better understanding of the disease will ultimately lead to the identification of targets and pathways for therapies to improve or cure the symptoms.

\section{Acknowledgements}

We are thankful to Dr. T. de Ravel for critical reading of the manuscript. We are grateful to all the patients, their families and caregivers who were willing to share their invaluable contribution, experience and insight into the disorder. H. Van Esch is clinical investigator at F.W.O. Vlaanderen.

\section{References}

-Aradhya S, Woffendin H, Bonnen P, Heiss NS, Yamagata T, et al: Physical and genetic characterization reveals a pseudogene, an evolutionary junction, and unstable loci in distal Xq28. Genomics 79:31-40 (2002).

- Auber B, Burfeind P, Thiels C, Alsat EA, Shoukier $\mathrm{M}$, et al: An unbalanced translocation resulting in a duplication of Xq28 causes a Rett syndrome-like phenotype in a female patient. Clin Genet 77:593-597 (2010).

- Bartsch O, Gebauer K, Lechno S, Van Esch H, Froyen G, et al: Four unrelated patients with Lubs X-linked mental retardation syndrome and different Xq28 duplications. Am J Med Genet A 152A:305-312 (2010).

-Bauters M, Van Esch H, Friez MJ, BoespflugTanguy $\mathrm{O}$, Zenker $\mathrm{M}$, et al: Nonrecurrent MECP2 duplications mediated by genomic architecture-driven DNA breaks and breakinduced replication repair. Genome Res 18: 847-858 (2008).

Belligni EF, Palmer RW, Hennekam RC: MECP2 duplication in a patient with congenital central hypoventilation. Am J Med Genet A 152A:1591-1593 (2010).

Carvalho CM, Zhang F, Liu P, Patel A, Sahoo T, et al: Complex rearrangements in patients with duplications of MECP2 can occur by fork stalling and template switching. Hum Mol Genet 18:2188-2203 (2009).

Clayton-Smith J, Walters S, Hobson E, BurkittWright E, Smith R, et al: Xq28 duplication presenting with intestinal and bladder dysfunction and a distinctive facial appearance. Eur J Hum Genet 17:434-443 (2009).
Collins AL, Levenson JM, Vilaythong AP, Richman R, Armstrong DL, et al: Mild overexpression of MeCP2 causes a progressive neurological disorder in mice. Hum Mol Genet 13:2679-2689 (2004).

del Gaudio D, Fang P, Scaglia F, Ward PA, Craigen WJ, et al: Increased MECP2 gene copy number as the result of genomic duplication in neurodevelopmentally delayed males. Genet Med 8:784-792 (2006).

Echenne B, Roubertie A, Lugtenberg D, Kleefstra T, Hamel BC, et al: Neurologic aspects of MECP2 gene duplication in male patients. Pediatr Neurol 41:187-191 (2009).

Fernandez RM, Nunez-Torres R, GonzalezMeneses A, Antinolo G, Borrego S: Novel association of severe neonatal encephalopathy and Hirschsprung disease in a male with a duplication at the Xq28 region. BMC Med Genet 11:137 (2010).

Friez MJ, Jones JR, Clarkson K, Lubs H, Abuelo $\mathrm{D}$, et al: Recurrent infections, hypotonia, and mental retardation caused by duplication of $M E C P 2$ and adjacent region in Xq28. Pediatrics 118:e1687-e1695 (2006).

Gargiulo A, Auricchio R, Barone MV, Cotugno $\mathrm{G}$, Reardon W, et al: Filamin A is mutated in $\mathrm{X}$-linked chronic idiopathic intestinal pseudo-obstruction with central nervous system involvement. Am J Hum Genet 80:751-758 (2007).
Grasshoff U, Bonin M, Goehring I, Ekici A, Dufke A, et al: De novo MECP2 duplication in two females with random X-inactivation and moderate mental retardation. Eur J Hum Genet 19:507-512 (2011).

Hehr U, Hehr A, Uyanik G, Phelan E, Winkler J, Reardon W: A filamin A splice mutation resulting in a syndrome of facial dysmorphism, periventricular nodular heterotopia, and severe constipation reminiscent of cerebro-fronto-facial syndrome. J Med Genet 43: 541-544 (2006).

Kirk EP, Malaty-Brevaud V, Martini N, Lacoste $C$, Levy N, et al: The clinical variability of the $M E C P 2$ duplication syndrome: description of two families with duplications excluding L1CAM and FLNA. Clin Genet 75:301-303 (2009).

Lachlan KL, Collinson MN, Sandford RO, van Zyl B, Jacobs PA, Thomas NS: Functional disomy resulting from duplications of distal $\mathrm{Xq}$ in four unrelated patients. Hum Genet 115:399-408 (2004).

Lubs H, Abidi F, Bier JA, Abuelo D, Ouzts L, et al: XLMR syndrome characterized by multiple respiratory infections, hypertelorism, severe CNS deterioration and early death localizes to distal Xq28. Am J Med Genet 85: 243-248 (1999).

Lugtenberg D, Kleefstra T, Oudakker AR, Nillesen WM, Yntema HG, et al: Structural variation in Xq28: $M E C P 2$ duplications in $1 \%$ of patients with unexplained XLMR and in $2 \%$ of male patients with severe encephalopathy. Eur J Hum Genet 17:444-453 (2009). 
Luikenhuis S, Giacometti E, Beard CF, Jaenisch $\mathrm{R}$ : Expression of $\mathrm{MeCP} 2$ in postmitotic neurons rescues Rett syndrome in mice. Proc Natl Acad Sci USA 101:6033-6038 (2004).

-Makrythanasis P, Moix I, Gimelli S, Fluss J, Aliferis K, et al: De novo duplication of $M E C P 2$ in a girl with mental retardation and no obvious dysmorphic features. Clin Genet 78:175-180 (2010).

Meins M, Lehmann J, Gerresheim F, Herchenbach J, Hagedorn M, et al: Submicroscopic duplication in Xq28 causes increased expression of the MECP2 gene in a boy with severe mental retardation and features of Rett syndrome. J Med Genet 42:e12 (2005).

- Prescott TE, Rodningen OK, Bjornstad A, StrayPedersen A: Two brothers with a microduplication including the $M E C P 2$ gene: rapid head growth in infancy and resolution of susceptibility to infection. Clin Dysmorphol 18:7882 (2009).
Ramocki MB, Peters SU, Tavyev YJ, Zhang F, Carvalho CM, et al: Autism and other neuropsychiatric symptoms are prevalent in individuals with $\mathrm{MeCP} 2$ duplication syndrome. Ann Neurol 66:771-782 (2009).

Ramocki MB, Tavyev YJ, Peters SU: The MECP2 duplication syndrome. Am J Med Genet A 152A:1079-1088 (2010)

Reardon W, Donoghue V, Murphy AM, King MD, Mayne PD, et al: Progressive cerebellar degenerative changes in the severe mental retardation syndrome caused by duplication of MECP2 and adjacent loci on Xq28. Eur J Pediatr 169:941-949 (2010).

Sanlaville D, Prieur M, de Blois MC, Genevieve D, Lapierre JM, et al: Functional disomy of the Xq28 chromosome region. Eur J Hum Genet 13:579-585 (2005).

Smyk M, Obersztyn E, Nowakowska B, Nawara $M$, Cheung SW, et al: Different-sized duplications of Xq28, including MECP2, in three males with mental retardation, absent or delayed speech, and recurrent infections. Am J Med Genet B Neuropsychiatr Genet 147B:799-806 (2008).
Vandewalle J, Van Esch H, Govaerts K, Verbeeck J, Zweier C, et al: Dosage-dependent severity of the phenotype in patients with mental retardation due to a recurrent copy-number gain at Xq28 mediated by an unusual recombination. Am J Hum Genet 85:809-822 (2009).

- Van Esch H, Bauters M, Ignatius J, Jansen M, Raynaud M, et al: Duplication of the MECP2 region is a frequent cause of severe mental retardation and progressive neurological symptoms in males. Am J Hum Genet 77: 442-453 (2005).

-Velinov M, Novelli A, Gu H, Fenko M, Dolzhanskaya N, et al: De-novo $2.15 \mathrm{Mb}$ terminal Xq duplication involving MECP2 but not L1CAM gene in a male patient with mental retardation. Clin Dysmorphol 18:9-12 (2009). 